\author{
Dariusz Leszczyński ${ }^{1}$ \\ Warsaw School of Economics, Poland
}

\title{
Emerging Varieties of Capitalism in Transition Countries: Literature Review
}

\begin{abstract}
The systemic transformation of post-socialist countries from central planning to a market economy was a very complex and unprecedented undertaking. In this study we critically examine three influential classifications proposed by Coates [2000, 2006], Hall and Soskice [2001], and Amable [2003], within the "comparative capitalisms" literature stream, and argue that they are unsuitable for evaluating the progress made by transition economies since 1990. The basis of the criticism stems from timing: these theoretical frameworks were developed primarily to evaluate the growth of advanced and mature capitalist countries. Thus, they fail to capture the unique features of transition economies and the complexity of the transformation process that led to the emergence of different market-based systems. From this vantage point, we discusses and also critique a recent classification developed by Myant and Drahokoupil [2011, 2015], who distinguish five ideal models (i.e. "varieties of capitalism") that have evolved within transition countries. In our conclusion we point to areas within the field that may be explored by future research.
\end{abstract}

Keywords: comparative capitalism, international integration, systemic transformation, transition countries, varieties of capitalism.

JEL: E01, E02, E10, F10

\section{Introduction}

Karl Polanyi, a well-known Hungarian-American political economist, understood the capitalist economy as an "instituted process" [Polanyi, 2001, pp. 45-58]. According to this 
point of view, capitalism may be regarded as a specific type of economy that "must be based in an institutionalized social order by and into which it is formed and organized" [Streeck, 2010, p. 5]. The distinct characteristics of this system (e.g. private property, free markets, wage labor, joint-stock companies, modern finance, etc.) came into existence and developed within diverse historical contexts, national traditions, institutional frameworks, as well as prevailing power structures that imprinted themselves in various ways within different societies [Streeck, 2010, p. 5]. Thus, the change and development of these political and economic institutions over time may lead to the emergence of various forms (i.e. types) of a capitalist system within different countries.

This paper critically examines the literature on the "varieties of capitalism" phenomenon by considering three influential approaches advanced by Coates [2000, 2006], Hall and Soskice [2001] and Amable [2003]. These well-known works investigate comparative capitalist systems, providing relevant and insightful classifications. However, their theoretical frameworks fail to capture the developments in economic and political systems of post-socialist countries, which underwent systemic transformation from central planning to a market economy. The frameworks instead focus on the analysis of stable and mature capitalist economies. Thus, to better understand the complexity and the uniqueness of the process undertaken by transition countries we need to include a broader range of variables (e.g. forms of international integration, state capacity, financial system requirements, etc.) to more fully explain the diversity of the capitalist systems that emerged within post-socialist nations since 1990 .

The transition countries (e.g. Russia, Poland or Ukraine, etc.) differ from other emerging capitalist economies (e.g. Mexico, Indonesia or Turkey, etc.) because these nations underwent complex structural reforms and institutional changes with the goal of establishing and developing market-based institutions (e.g. price liberalization, the removal of existing trade barriers, the reform of property rights, privatization of state-owned enterprises, the development of a private financial sector, etc.). This systemic transformation process commenced in 1990 within the former Soviet Union and its satellite states located in the Central and Eastern Europe, which were part of the so called "Soviet Bloc" [Maszczyk, Rapacki, 2012].

In an attempt to extend the research on "comparative capitalisms, "the author discusses and critically reviews a recent classification advanced by Myant and Drahokoupil [2011, 2015], who investigated post-socialist economies undergoing systemic transformation in Central and Eastern Europe (CEECs), South East Europe (SEECs), and the Commonwealth of Independent States (CIS). Based on empirical data, they distinguished five models of "varieties of capitalism" that emerged within these transition countries since 1990. We hope that this comprehensive classification provides a framework for future research in this area 


\section{Overview of Standard "Varieties of Capitalism" Typologies}

Modern capitalism is a complex system that can be analyzed in four different dimensions, namely: economic, psychological, political, and societal. These dimensions comprise several distinct characteristic features, which all capitalist nations share but their extent and pattern vary. For example, the economic dimension entails: "private ownership of the means of production"; "market monetary exchange of commodities for profit"; "competition between units of capital"; and "wage labor." The observed differences are for typologies proposed by researchers within the "comparative capitalism" field of research [Lane, 2005, pp. 228-229].

Lane defines modern capitalism as "a system of production taking place for global market exchange [that utilizes] money as a [medium of exchange, which] determines differentials of income, levels of investment and the distribution of goods and services." In such an economic system, productive assets are privately owned either by individuals or various organizations, while a major objective of economic life is the pursuit of profit that enables the accumulation of capital for investment purposes. The role of government, embedded in a pluralistic society, is restricted to " [the provision of] an effective system of law, securing private property, and [the] rights of [the] owners over the proceeds of production" [2007, p. 16].

During the 21st century, the literature on the "varieties of capitalism" has been considerably extended. In this paper, three popular frameworks proposed by Coates [2000, 2006], Hall and Soskice [2001], and Amable [2003], are presented and critically evaluated. These scholars provide various "paradigms" of capitalism, each with its distinct characteristics and complementarities. These typologies explain the institutional similarities and differences between mature and stable developed economies. They form the basis for distinguishing the "varieties of capitalism" that prevail in various advanced capitalist nations.

The theoretical approach proposed by Hall and Soskice [2001] draws a distinction between two different models of coordination that characterize firm activities. Thus, the scholars identify two models of coordination, which exist within modern capitalism. The first category was referred to as "liberal market economies" (i.e. LME), while the second distinguished type was called the "coordinated market economies (i.e. CME) [Hall, Soskice, 2001, pp. 6-54].

In the LME model of capitalism, enterprises run their activities and coordinate with other agents by competitive markets, which are characterized by arms-length relations, as well as formal contracting. This model of coordination favors investment in transferable assets. This type of market-based economy may be found in English-speaking countries such as the USA, the UK, Canada, Australia, and New Zealand [Hall, Soskice, 2001, pp. 6-54]. The LME model exhibits a high level of complementarity between various institutions and processes. The characteristics of "liberal market economies" are: "high 
levels of stock market capitalization"; "low levels of employment protection;" "high levels of paid employment;" and "high income inequality" [Lane, 2005, pp. 229-230]. The economic agents are involved in many complex mergers and acquisitions transactions, which are facilitated by highly developed, innovative financial markets.

In the CME model, the enterprises coordinate their activities with other agents through many non-market relationships. This form of coordination occurs through the processes of strategic interaction, which can be explained and modeled by the propositions of the game theory. This model of coordination favors investment in specific assets. Typical examples of the CME model are Germany, Denmark, France, and Japan. The "coordinated market economies" exhibit such distinct features as "high levels of employment protection", "low stock market capitalization;" "relatively lower numbers of working hours" and "relatively low differentials of income inequality". In the CME model mergers and acquisitions occur rarely, while trade unions protect the interests of labor. Moreover, the enterprises are coordinated by many vertical or horizontal linkages that exist between firms on the market [Hall, Soskice, 2001, pp. 6-54].

This classification has three major limitations. One is that it only considers one dimension of capitalist economies, dealing with the coordination processes of the economic agents. Based on a single criterion when developing this typology, scholars include into one model (i.e. either the LME or the CME type) very diverse economies. For example, Japan and Germany, which are grouped within the CME category, exhibit very different types of welfare systems for their citizens, as well as different forms of integration with the world economy. Moreover, countries like the United Kingdom, Canada and the USA (all classified within the LME group) also display some diversity concerning welfare provisions for their residents, as well as linkages with the global economy [Lane, 2005, p. 230].

The second limitation of this framework is that when other criteria are applied to distinguish the "varieties of capitalism" in advanced market economies (e.g. industrial profile of a country, the channel of international integration, the forms of innovation adopted, different types of ownership and control mechanisms, etc.), a different combination of country groupings emerges. Thus, a different typology could be established from the one presented by Hall and Soskice [2001] in their approach [Lane, 2005, p. 230].

The third major criticism concerns an underestimation of diversity of the capitalist systems existing in the modern world economy. As a result, the authors introduced a bias, which reduced their reasoning to static terms. For instance, the scholars failed to consider a variety of market-based systems that emerged within the post-socialist countries undergoing systemic transformation from central planning to a market economy. Therefore, over time due to many criticisms, the "varieties of capitalism" approach proposed by Hall and Soskice [2001] has lost its dominant position within the "comparative capitalisms "research theory. However, it still remains influential in studying the different models of capitalist systems in the global world economy [Ebenau et al., 2015, pp. 1-2]. 
David Coates [2000, 2006] and Bruno Amable [2003] modified the approach developed by Hall and Soskice [2001] by including additional variables, such as product and market competition; wage labor; labor market institutions; the financial intermediation sector; corporate governance issues; social protection schemes; and the notion of a welfare state.

Coates [2000, 2006] identified three models of capitalist economic systems. The first category was called "Market-led capitalism", where private enterprises pursue short-term profit goals and obtain capital funding in the open financial market. In such an economic system, the government's involvement is limited to establishing and protecting markets, while labor has restricted statutory industrial, as well as social rights. This type of capitalism is present in English-speaking countries like the United States and the United Kingdom.

The second type is identified as "State-led capitalism," where business objectives and capital funding are also the responsibility of private enterprises. However, in this model firms make strategic decisions through close liaison with the government agencies. Under "State-led capitalism", labor lacks strong statutory industrial and social rights, but workers enjoy much closer relations with private enterprises through "company-based welfare provision". Typical representatives of this system are countries like Japan and South Korea.

The third is called "Negotiated or consensual capitalism". In this model, government regulation of the market is relatively limited, but the position of labor unions is strong. Thus, they enforce the workers' rights and social security benefits. Moreover, organized labor unions are directly engaged in the corporate decision-making processes of the enterprises. Typical examples of this system are countries like Germany and Sweden [Coates, 2006, pp. 6-11].

In turn, Amable [2003] distinguished five "varieties of capitalism" of developed market economies using the following criteria: the nature of product markets (i.e. regulated or deregulated); the features of labor markets (i.e. flexible or regulated); the type of prevailing capital finance (i.e. regulated stock markets or commercial banks); the extent and type of welfare state developed; as well as the nature of the education system (i.e. public or private) [Amable, 2003, pp. 171-181].

The first model was called the "Market-based capitalism". This type is similar to those developed by the Hall and Soskice's [2001] LME and the Coates's [2000, 2006] "Market-led capitalism". The second model was entitled the "Social-democratic capitalism" and its distinct features include: moderate employment protection for the workforce, high level of social welfare, and easy access to training for labor. This type exhibits a coordinated wage-bargaining system, enabling a more systematic wage-setting that favors innovation and productivity. Examples of this capitalist system are countries like Denmark, Finland, and Sweden. Moreover, the "Social-democratic capitalism" model is similar to the "Negotiated or consensual capitalism", distinguished by Coates [2000, 2006]. The third model, called the "Continental European capitalism", resembles the "Social-democratic capitalism" category described earlier. However, this model is based on a higher degree 
of employment protection and a less-developed welfare state, examples of which include Germany, France, the Netherlands, Belgium, and Switzerland [Amable, 2003, pp. 171-181].

The fourth capitalist system, referred to as the "Mediterranean capitalism" model, exhibits more employment protection for workers but less social protection in comparison with the "Continental European Capitalism" type. Labor protection is exercised through a relatively low-level market competition, and the lack of short-term constraints because of a centralized financial system. Representative examples include Italy, Spain, Portugal, and Greece. The last identified type was called the "Asian capitalism" model. This model is a "State-led capitalism" type proposed by Coates [2000, 2006]. It is highly dependent on corporate business strategies, which are developed in close collaboration with government agencies. The "Asian capitalism" model relies heavily on a centralized financial system that enables the enterprises to formulate long-term strategies. Large corporations provide security for the workforce by retraining, and providing employees with long-term career prospects [Amable, 2003, pp. 171-181].

The major drawback of the standard "varieties of capitalism" theoretical frameworks developed by Coates [2000, 2006], Hall and Soskice [2001], and Amable [2003] is that these classifications are predominantly concerned with analyzing stable, mature market economies. These countries are at a high level of economic development and share a long history of being classified as capitalist nations. On the other hand, all post-socialist countries, which introduced some form of market reform since 1990, display many non-capitalist system features. Thus, these distinct characteristics make the direct adoption of above-described standard "varieties of capitalism" approaches difficult to apply in practice to post-socialist economies.

Many researchers criticized the standard "varieties of capitalism" conceptual frameworks suggesting that these approaches fail to capture the complexity of the changes and progress involved in transformation from central planning to market-based economies [Bohle et al., 2007; Lane, 2007; Myant, Drahokoupil, 2011; Hardy, 2014]. Thus, applying the models proposed by Coates [2000, 2006], Hall and Soskice [2001], and Amable [2003] to the specific conditions of transition countries in the CEECs, SEECs and CIS groups may not be possible or desirable because these nations exhibit inherited ownership and market coordination patterns that are substantially different from those found in developed capitalist nations.

In the former socialist countries the government played an important role as the coordinator of the centrally planned economy. The state exercised public ownership of resources, controlled the supply of domestic currency, and made strategic decisions concerning major investments in the economy. Moreover, the central government determined employment levels, regulated wages, and set the division between personal and public expenditure levels. All former socialist nations developed a relatively advanced industrial base, displayed high literacy among citizens, and exhibited a reasonable level of educational attainment in society [Lane, 2005, p. 231]. 
Despite some positive achievements of the centrally planned economic system, these countries shared many negative characteristics, including deep macro-economic imbalances; a monopolistic structure of production; an authoritarian style of management; rent-seeking activities of economic agents; and the erosion of professional, as well as work, ethos. These adverse features of the "command economy" legacy strongly hindered transformation efforts to set up modern capitalist institutions. As a result, this long-term "socialist heritage" made a distinct footprint on these countries' economic and social systems (e.g. the behaviors of their citizens). Thus, the progress made by the post-socialist countries since 1990 substantially differed from the one accomplished by mature, stable market economies [Lane, 2005, p. 231].

In transition economies, many features of capitalism were compromised by: non-market economic relationships; the lack of a complementary ideology; inadequate market institutions; and the absence or shortage of experienced entrepreneurs and investors to launch new business undertakings. In short, these countries are still in the process of developing a mature and stable market system. Therefore, researchers studying the phenomenon of "varieties of capitalism" within post-socialist countries need to not only understand the different forms of market-based economies present within these nations, but also the extent to which a capitalist system has been formed in these societies. As a result, scholars should include other factors in their analysis to identify what type of capitalism was developed in a particular transition country [Lane, 2005, p. 231].

\section{The Unique Nature of the Transition Process from Central Planning to a Market Economy}

After the collapse of the communist economic system, the countries of Central and Eastern Europe (i.e. CEECs), Southeastern Europe (i.e. SEECs), and the Commonwealth of Independent States (i.e. CIS) embarked on the road of building a market-based system.

The process of transition commences when a country moves away from the characteristics of the socialist system (e.g. exclusive power of the communist party; dominant state ownership of enterprises; central planning and allocation of resources; soft budget constraints; market driven by the sellers; etc.). It is completed when a nation achieves a configuration that makes up the features of a capitalist system (e.g. government support of private property rights and market institutions; dominant private ownership of enterprises; allocation of resources by a free market; hard budget constraints; market driven by the buyers; etc.). This complex undertaking entails both systemic (e.g. privatization of state-owned enterprises) as well as non-systemic (e.g. devaluation of a local currency) changes in the economy and society of a particular country [Kornai, 2000, pp. 30-34]. 
The transition process can be viewed as either a movement toward a defined end result (i.e. transition) or a change without a specific objective in mind (i.e. transformation) [Myant, Drahokoupil, 2011, p. 299]. Heiduk and Rapacki [2009] argued that the overwhelming majority of former socialist countries commenced systemic transformation without a clearly defined outcome or set goal. However, the end results achieved by these actions, in terms of structural reforms and the building of market institutions, are diverse. As a result, thus far, no single type of capitalist system has emerged within transition countries but several market-based economies can be identified [Myant, Drahokoupil, 2011, p. 299]. The salient features of the socialist and the capitalist economic system are summarized in Table 1.

\section{TABLE 1. The characteristic features of socialist and the capitalist economic systems}

\begin{tabular}{|l|l|}
\hline Characteristic features of socialist economic system & Characteristic features of capitalist economic system \\
\hline Exclusive power of the communist party & $\begin{array}{l}\text { Elected political power supports private property } \\
\text { rights and market-based institutions }\end{array}$ \\
\hline Dominant state ownership of enterprises & Dominant private ownership of enterprises \\
\hline Coordination of resources by the state bureaucracy & Market coordination of resources \\
\hline Soft budget constraints & Hard budget constraints \\
\hline $\begin{array}{l}\text { Weak responsiveness to the price mechanism by } \\
\text { economic agents }\end{array}$ & $\begin{array}{l}\text { Strong responsiveness to the price mechanism by } \\
\text { economic agents }\end{array}$ \\
\hline Plan bargaining by the economic agents & No central planning in the economy \\
\hline $\begin{array}{l}\text { Focus on the quantity of output, but not quality or } \\
\text { customer satisfaction }\end{array}$ & $\begin{array}{l}\text { Focus on the quality and quantity of output, as well } \\
\text { as customer satisfaction }\end{array}$ \\
\hline Chronic shortages in the economy & No chronic shortages in the economy \\
\hline Shortage of skilled labor & Abundance of skilled labor \\
\hline Market driven by the sellers (supply) & Market driven by the buyers (demand) \\
\hline Hidden unemployment in the economy & Structural and cyclical unemployment \\
\hline $\begin{array}{l}\text { Business cycle fluctuations not necessarily relevant } \\
\text { for output and the employment level }\end{array}$ & $\begin{array}{l}\text { Business cycle fluctuations affect output and the } \\
\text { employment level }\end{array}$ \\
\hline
\end{tabular}

S o u r c e: own elaboration based on Kornai [2000, pp. 28-30].

The different institutional characteristics of transition economies and diverse forms of capitalism developed by these nations can be attributed to many factors. Firstly, different varieties of socialism evolved between 1945 and 1989 within the former socialist nations despite sharing many common systemic political and economic features imposed by the Soviet Union. Thus, the communist system legacy that shaped initial conditions for the systemic transformation in all these economies also varied within post-socialist countries. Secondly, the institutional development trajectory differed in each nation. It was highly influenced by historical traditions and the institutional endowment inherited by transition economies from their past national heritage [Maszczyk, Rapacki, 2012, p. 137]. Finally, 
the last major factor associated with the selection of a particular transformation strategy involved the speed of reform (i.e. "shock therapy" versus a "gradualist approach"). This choice between strategies was highly influenced by existing political and institutional conditions, as well as the overall macroeconomic situation of each country prevailing at the beginning of the systemic transformation process. For instance, Poland experienced "deep macroeconomic disequilibria" while at the same time the former Czechoslovakia displayed a relatively "stable and balanced economic situation." The different political, institutional and macroeconomic conditions present in 1989 within the post-socialist economies provide a plausible explanation for why some countries adopted the "shock therapy" approach (e.g. Poland), while other countries implemented a "more gradualist transformation policy" (e.g. the former Czechoslovakia). This second alternative depended much more on strategic coordination then on the market mechanism [Maszczyk, Rapacki, 2012, p. 138].

\section{The Problems of Including Transition Countries within the Standard "Varieties of Capitalism" Classifications}

The well-known typologies within the "comparative capitalisms" literature developed by Coates [2000, 2006], Hall and Soskice [2001], and Amable [2003] do not appear to be applicable to the analysis of the progress of transition countries since 1990, as those theoretical frameworks were used to evaluate the differences in the development levels of the mature and stable market economies. At the same time, transition countries continue to display specific characteristic features (see Table 1.) that are associated with the legacy of a "command economy". These peculiar features distinguish post-socialist nations from developed capitalist economies, making the standard "varieties of capitalism" frameworks difficult to implement in practice when evaluating the progress made by specific countries. Thus, the classifications mentioned above have limited direct application to many transition, emerging, or developing countries from different geographical locations.

The first identified limitation concerns the selection of a suitable dependent variable used to examine and explain the comparative economic performance of each transition economy [Maszczyk, Rapacki, 2012, p. 140]. For instance, under the "varieties of capitalism" proposition presented by Hall and Soskice [2001, pp. 1-6], the chosen independent variable for analysis was the dynamic capability of a nation to achieve a leading position within the global economy in a specific branch of economic activity on the basis of technological progress. However, thus far, we cannot identify a single transition country that managed to accomplish such a high level of development [Maszczyk, Rapacki, 2012, p. 140]. Post-socialist nations earn foreign currency to cover their import expenditures by exporting less sophisticated products that are manufactured using imported technology. Some of these 
countries also rely on other sources of foreign currency acquisition (e.g. remittances from migrant workers, direct capital inflows, etc.). Therefore, a better dependent variable for comparative purposes would be the adoption of a more general form of integration with the global economy, such as export competitiveness [Myant, Drahokoupil, 2011, p. 300].

The second highlighted limitation is associated with the selection of an appropriate independent variable. In advanced market countries, formal institutions and established rules of the game guide the behavior of economic agents. Thus, such institutions as "state capacity"; "the rule of law"; "a functioning system of corporate governance"; "a stable financial system"; "clarity in the ownership of enterprises"; and "a separation between the spheres of business and politics" are usually taken for granted [Myant, Drahokoupil, 2011, p. 301]. However, in transition economies, there is a significant gap between formal and informal institutions, as the latter play an important role of influencing the behavior of economic agents. This key aspect is not recognized within the standard "varieties of capitalism" typologies that investigated advanced market economies. As a result, in the case of transition countries, a proxy measure for this independent variable should be defined in a different manner than for developed capitalist nations, which have established and reliable institutions [Maszczyk, Rapacki, 2012, p. 140]. Moreover, formal and informal institutions influence various forms of international integration of the transition countries. However, institutions alone are insufficient independent variables in the analysis of the "varieties of capitalism" that emerged in post-socialist economies since 1990 since we can identify many other factors (e.g. "the structure of the inherited industrial bases", "natural resource endowments", "geography", etc.) that also explain the diversity of their economic performance [Drahokoupil, Myant, 2015, pp. 155-160].

The third limitation refers to the fact that institutional preconditions determine the various forms of international integration of these countries with the world economy, as institutions can be regarded as a necessary, but they are not sufficient when classifying an economic system [Maszczyk, Rapacki, 2012, p. 140]. For instance, Myant and Drahokoupil [2011, pp. 301] mention "inherited economic structures", "the scope for new business development," as well as "the nature of welfare regimes" and their potential impact on prospective development, as important co-determinants of international competitiveness of transition economies. Moreover, the authors explain that these independent variables are rarely directly linked to different channels of integration with the world economy of post-socialist nations.

The last identified limitation relates to the fact that these approaches were developed under the assumption "of long-term continuity and the permanence of relationships" of formal institutions within market-based economies [Myant, Drahokoupil, 2011, p. 301]. However, the systemic transformation from central planning to a market economy, experienced by transition countries, involves "a high degree of discontinuity and volatility" which sharply contrasts with the conditions present within advanced market economies [Maszczyk, Rapacki, 2012, p. 140]. As a result, researchers are unable to identify those 
institutional features in post-socialist nations that are permanent and likely to exhibit a long-lasting impact on economic systems. Moreover, scholars also find it difficult to determine which systemic characteristics of these countries should be regarded as transient in nature [Myant, Drahokoupil, 2011, p. 301].

\section{Emerging "Varieties of Capitalism" in Transition Countries: A Proposed Tentative Classification}

In 1990, following the collapse of state socialism, a market system was introduced in almost all post-socialist economies from the Central and Eastern Europe (CEECs), South East Europe (SEECs) and members of the Commonwealth of Independent States (CIS). The new system introduced private ownership of assets and the means of production and new profit incentives [Lane, 2007, pp. 33-34]. Almost all former socialist countries adopted some characteristics of a market economy to build "capitalist societies" in some form or another. However, the different experiences and starting points of these countries led to the diversity of their performance and economic progress. Thus, the peculiar features of transition countries that differ from mature and stable market economies are important for identifying the "varieties of capitalism", which have emerged in these nations since 1990 [Myant, Drahokoupil, 2010, p. 7].

Recognizing the uniqueness and historically unprecedented nature of the systemic transformation process from central planning to a market economy requires an adjustment of the standard "varieties of capitalism" frameworks to include the peculiar features of post-socialist countries. The first step in developing a new, more suitable classification for evaluating these countries, should begin with identifying the different forms of integration with the world economy [Maszczyk, Rapacki, 2012, p. 141]. For this purpose, Myant and Drahokoupil [2011, pp. 62-79] determined six different channels of international integration based on such criteria as "the trade balance and the share of export of goods and services in GDP", "changing export structures", "financial flows", "foreign direct investment", and "remittances and aid".

The first form was called "Export-oriented foreign direct investment (FDI) in complex sectors". In this case, international integration occurs through the business activities of large multinational companies (MNCs) and their local subsidiaries established in transition economies. These enterprises export high-value products mainly to Western markets, manufactured using sophisticated technologies and various forms of innovation. Foreign direct investment by MNCs in post-socialist countries required a relatively well functioning government, developed business environment that guaranteed the safety of their operations, complex network of relationships with enterprises and local and central government agencies [Myant, Drahokoupil, 2011, pp. 303-304]. Most of these preconditions 
for MNCs' involvement in transition economies were broadly met by the CEECs and, to a large extent, by the SEECs [Maszczyk, Rapacki, 2012, pp. 141-142].

The second type was referred to as the "Export-oriented complex sectors without FDI". It should be treated as an exception from the pattern discussed earlier. This form of international integration was experienced by some of the most economically developed transition countries (e.g. Czech Republic, Slovenia). Their export-oriented companies, which manufactured fairly modern products, managed to compete with some success in demanding Western European markets [Myant, Drahokoupil, 2011, pp. 304-305]. This type was also present on a limited scale in some post-socialist economies, such as Russia or Belarus, which are important manufacturers of armaments and commodity exporters. In turn, the latter countries exported vehicles produced by government-owned firms with major financial support from state-directed banks [Maszczyk, Rapacki, 2012, pp. 141-142]. These countries could only compete successfully in less competitive markets not dominated by established MNCs [Myant, Drahokoupil, 2011, pp. 304-305].

The third form was called "Simple manufacturing subcontracting to MNCs". It depended on exports of processed or semi-processed products (e.g. garments, footwear or simple components) that required medium to low technology levels with low value added, and was dependent on subcontracting from MNCs. However, the entire product development stage was carried out in mature market economies [Myant, Drahokoupil, 2011, p. 305]. This category of international integration played an important role within the CEECs in the early $1990 \mathrm{~s}$ and in the SEECs. It could also be observed in some lower-income transition economies (e.g. Ukraine) and countries from the Central Asia (e.g. Kyrgyzstan, a member of the CIS), though on a very small scale [Maszczyk, Rapacki, 2012, pp. 141-142]. This form of integration with the world economy required an adequate transportation and communication infrastructure, secure legal environment, and low labor costs. Consequently, this type of integration occurred only as a temporary phase in CEECs countries, and other countries soon began exporting relatively high quality products requiring more sophisticated technologies [Myant, Drahokoupil, 2011, p. 305].

The fourth type was referred to as "Commodity exports". This form of international integration was important for CEECs in the early years of the transition. However, as transformation to a market-based economy advanced, its role diminished due to foreign direct investments by MNCs. These foreign-owned enterprises provided CEECs with more capital for export potential of more complex products [Myant, Drahokoupil, 2011, pp. 305-306]. However, this channel of integration with the world economy played a very important role in the oil-exporting countries (e.g. Russia, Kazakhstan, and Azerbaijan) and was also important for Ukraine, which is a known exporter of steel and chemicals [Maszczyk, Rapacki, 2012, p. 142]. In these countries, exports were carried out by aging local enterprises, which exploited outdated technology inherited from the socialist system. The problem of relying primarily on the commodity exports is that they provide highly volatile income streams involving frequent price changes during different business cycles. 
This problem is usually not present in exports of high-quality manufactured products [Myant, Drahokoupil, 2011, pp. 305-306].

The fifth form was called "Dependence on remittances and aid" and was used by transition countries to compensate for substantial trade deficits as local enterprises failed to supply competitive goods for export [Myant, Drahokoupil, 2011, p. 306]. This channel of international integration was most prevalent within the lowest-income transition economies (e.g. Albania). The linkage with the world economy occurred through temporary or permanent emigration of citizens from CEECs, SEECs and the CIS group to developed Western European countries or Russia (in case of the members of the Commonwealth of Independent States), who then transferred their earnings back home [Maszczyk, Rapacki, 2012, p. 142]. The remittance-based capitalist economy is compatible with a very low level of development of internal institutions (e.g. government capacity, infrastructure, business environment, etc.). The transfer of significant amounts of foreign-currency earnings from abroad by the citizens of these nations provided a stimulus for their local economies by boosting domestic consumer demand. The dependence on remittances and foreign aid in these nations provides no basis for more complex forms of international integration with the world economy and is subject to changing demand for labor in developed market economies [Myant, Drahokoupil, 2011, p. 306].

Finally, the sixth type is related to "Dependence on financialized growth". This channel of integration was a supplementary form of linkage between the transition countries and the world economy. International integration occurred through foreign borrowing and monetary inflows, which supported private-sector's activity [Myant, Drahokoupil, 2011, pp. 307-310]. The extent of "financialized growth" as a channel of international integration present within these countries is measured by the financial account balance of payments surpluses (excluding contributions received from FDI). This pattern of integration was, at some stages of the systemic transformation process, important for the development of several middle- to higher-income countries (e.g. Hungary, Belarus, Ukraine, and Kazakhstan). It was also present in a number of low-income Central Asian nations (e.g. Armenia, Georgia, Tajikistan, and Kyrgyzstan) [Maszczyk, Rapacki, 2012, p. 142]. "Financialized growth", as a form of integration with the world economy, was transient in its nature. This is because its impact on the post-socialist economies increased until the world financial crisis of 2007-2008, and then declined dramatically. [Myant, Drahokoupil, 2015, pp. 155-171].

The identification of different forms of integration with the world economy provides us with a good starting point for evaluating the progress of post-socialist nations since 1990. However, in the second step, we need to broaden the analysis by determining a set of internal factors, which better capture the unique features of transition countries [Maszczyk, Rapacki, 2012, p. 142]. For this purpose, Myant and Drahokoupil [2010] list five key internal factors that best describe the specific conditions of post-socialist nations.

The first factor is "the relations between politics and business". This variable deals with the separation of political power (i.e. the state) from economic power (i.e. control 
over enterprises). This factor also covers the extent to which the government can act as an impartial arbitrator to protect various business interests. In socialism, political and economic powers were merged under the state ownership of assets, as was the capital that financed them. During transition, private ownership cannot effectively ensure a separation of political from economic power as government can be influenced, or sometimes used, to serve the interests of particular business groups. This danger should be minimized by establishing democratic institutions, ensuring different representation of opinions, creating stable forms of interest, an independent media, and a well-informed, active public [Myant, Drahokoupil, 2010, p. 8].

The second factor is the "rule of law and the nature of property rights". This variable, which depends heavily on the previous internal factor, was taken for granted in the Hall and Soskice [2001] "varieties of capitalism" framework. However, the "rule of law" is not the only instrument used to protect private property rights. Another viable alternative is the security provided by the political power (i.e. the state), which often results in the emergence of "clientelistic networks". Comparative statistics regarding the rule of law, corruption, and the state capacity variables reveal a clear distinction between countries from the CIS group, most CEECs, as well as the SEECs. However, corruption at both the government and business levels still remains a serious problem in all transition economies [Myant, Drahokoupil, 2010, pp. 8-10].

The third factor is the "economic role of the state". This variable is gauged by two measures, namely: "the share of public spending in GDP", and "the scale of the budget deficit". These indicators relate to "the capacity of the state to function", "the extent of welfare spending", and "the active role of the state in promoting economic development". The CEECs and many SEECs largely avoided a breakdown in the state capacity institution, which was experienced within most nations from the CIS group. This development resulted in the disintegration of the rule of law, escalation of crime and corruption, and general chaos. Most CEECs and many SEECs also managed to maintain broadly balanced budgets. However, large differences exist in the scale of budget deficits between many transition countries within these two groups, reflecting their welfare spending levels. All transition economies provided public support for education at various levels, and most of these countries also fostered the R\&D funding. However, the scale of financial assistance rendered by the state for the latter was far below the levels reported by advanced capitalist countries. Transition nations were neither very active in promoting the development of different forms of innovation nor efficacious supporters of emerging high-tech firms [Myant, Drahokoupil, 2010, pp. 10-11].

The fourth factor is the "structure of business". Estimates by The European Bank for Reconstruction and Development (EBRD) of the extent of private ownership in transition countries reveals a general pattern where over $70 \%$ of GDP is generated from a broadly-defined private sector in almost all of them. More visible distinctions among transition economies are revealed when business structure is analyzed in terms of "the extent of foreign 
ownership", "the concentration of domestic ownership", and "the scope for new business development". Within CEECs, high levels of foreign ownership in finance, the retail trade and much of industry are present. Within the CIS group, lower levels of foreign ownership exist, except in particular commodity-exporting countries (e.g. Kazakhstan, Azerbaijan). For instance, a high concentration of domestic private ownership was observed in Russia, where large-scale businesses remained in the hands of the so-called "oligarchs" who accumulated their wealth over time by maintaining very close relationships with ruling political elites. Self-employment figures are higher in the CEECs group, and noticeably lower in many members of the CIS (e.g. Russia) [Myant, Drahokoupil, 2010, pp. 11-12].

Finally, the fifth factor relates to the presence of "finance systems". The development of these systems warrants "high levels of trust" achieved through "long-term experience" and the existence of "complex legal and regulatory frameworks". The indicator "credits as a proportion of GDP" displays the extent of lending that is present in transition economies. This figure was much lower in countries undergoing transformation than in advanced capitalist countries. However, in most transition countries, credits were extended at levels high enough to show the gradual development of financial markets. Though this measure remained comparatively weak within several CIS group members. For instance, in Russia, the banking system experienced a rather turbulent development throughout the transition period, contributing to a rather poor business environment for establishing and growing new firms [Myant, Drahokoupil, 2010, p. 13].

Moreover, other forms of raising capital for businesses in the CIS group (e.g. the sale of shares on stock exchanges) were reported to be at consistently low levels. In case of the "deposits as a proportion of GDP" indicator, only a few transition countries managed to accumulate sufficient deposits to meet the credit needs of their economies (e.g. Croatia, Czech Republic). The development of a substantial deposit base in these countries required that households and private enterprises gained enough trust in a transforming banking industry to establish the habit of saving money. This was a rather slow process, especially during the early 1990 s, when many CEECs, SEECs and CIS countries suffered from "extreme economic instability and hyperinflation". Moreover, some countries (e.g. Estonia, Latvia, and Lithuania) had to rely heavily on external funding to develop their economies. This form of international integration was referred to earlier as "financialized growth" and was a rather dangerous phenomenon for the long-term economic stability [Myant, Drahokoupil, 2010, p. 13].

In the third and final step, the six forms of international integration can be combined with the five internal factors to arrive at a tentative classification of five ideal models (i.e. "varieties of capitalism") that emerged within transition countries since 1990 [Myant, Drahokoupil, 2011, p. 310].

The first distinguished model was referred to as the "FDI-based (second-rank) market economies". It is best described by CEECs (e.g. the Czech Republic, Poland, and Slovakia). These transition countries exhibit such features as "democratic political systems", 
"the integration into the EU" [i.e. the European Union], as well as "export structures increasingly built around [highly-processed] manufactured goods produced by foreign-owned MNCs" [Drahokoupil, Myant, 2015, pp. 155-171]. The CEECs managed to develop rather complex export structures. However, these countries have only played a secondary role in global production markets and networks and lack the sophisticated business infrastructure needed to develop a high-tech innovation capacity (e.g. access to venture and private equity capital; established large domestic enterprises in high-tech industries; strong R\&D bases; etc.) [Maszczyk, Rapacki, 2012, pp. 142-143]. On the other hand, these countries have built a sound environment to foster the establishment and growth of domestic private enterprises. Moreover, the CEECs display a wide diversity of flexible labor market institutions (i.e. labor protection and welfare systems) that range from the more conservative "Continental European capitalism" model to the neo-liberal AngloSaxon "Market-based capitalism" variety, as identified by Amable [2003]. In conclusion, many of these nations have considerable potential for further development into mature and stable capitalist economies in the future, and are the most promising category, relative to the other distinguished "ideal models" of market-based systems, to have emerged from systemic transformation since 1990 [Drahokoupil, Myant, 2015, pp. 155-171].

The second variety was called "peripheral market economies". This category can be found within SEECs (e.g. Bulgaria) and in some CEEC countries (e.g. Estonia, Latvia, and Lithuania). These countries have adopted rather stable democratic political systems and developed a basic legal, as well as institutional, environment for private business [Drahokoupil, Myant, 2015, pp. 155-171]. "Peripheral market economies" also provide a relatively low level of welfare payments to their citizens, exhibit large income disparities, and tend to experience a comparatively lower level of development. They therefore tend to largely depend on the "financialized growth" pattern of international integration including significant dependence on remittances. As a result, these countries are not adequately prepared to withstand external shocks during unfavorable business cycles [Maszczyk, Rapacki, 2012, p. 143].

Moreover, these countries rely on exports of unsophisticated and less-stable manufactured goods, as well as raw material exports. This form of international integration was also important in CEECs during the early $1990 \mathrm{~s}$. However, the systemic transformation process led to higher wage levels in their economies, making it very difficult for them to compete with emerging Asian countries in the production of simple manufactured goods (e.g. garments, footwear, etc.) [Drahokoupil, Myant, 2015, pp. 155-171]. The leading countries within this variety of capitalism (e.g. Estonia) may progress to the first category. To make this transition, they have to develop an export-oriented manufacturing capacity within more complex sectors of the economy. Moreover, other less-developed transition countries that are currently classified within other variety types (see Table 1.) may also join this group in the future. However, they need to undertake more radical political and economic reforms [Maszczyk, Rapacki, 2012, p. 143]. 
The third variety of capitalism can be described as an "oligarchic (clientelistic) capitalism" because it exhibits close links between business and political power. This category is represented by CIS members, particularly Russia, Ukraine, Azerbaijan and Kazakhstan [Drahokoupil, Myant, 2015, pp. 155-171]. These countries share relatively authoritarian political systems and higher occurrence of rent seeking resulting from close relationships between political power and strategic enterprise owners. Furthermore, they exhibit lower levels of state capacity in the form of social welfare, institutional, and regulatory frameworks. As a result, private business expansion and the innovative capability of firms is generally underdeveloped. In the "oligarchic (clientelistic) capitalism" model, commodity-exporting strategic enterprises can prosper in the absence of a stable legal and business environment so long as they receive sufficient support from political power elites. For instance, in Russia powerful business ownership groups (i.e. "the oligarchs") established themselves during transformation, and significantly benefited from the privatization policies introduced by political power elites during the 1990 s [Maszczyk, Rapacki, 2012, p. 143]. But in these countries, the ownership of private property is not protected by sound market-based institutions and cannot be enjoyed with the same level of security experienced in advanced capitalist economies. As a result, expropriation of private assets by political power elites is a constant threat. On the other hand, powerful oligarchs have considerable influence over politicians through election campaign financing, and controlling the mass media to promote favored candidates. Moreover, the wealth generated from the oil and gas exports can be "a force for economic and social inertia" that traps these nations within the existing "oligarchic (clientelistic) capitalism" structure. This market-based system restricts their ability to compete in international markets with non-commodity related goods and services. The likely progress of these countries requires radical political, economic, and social system changes to break down prevailing relationships between business interests and politics, which hinder new business development and innovation within the non-commodity exporting sectors of the economy [Drahokoupil, Myant, 2015, pp. 155-171].

The fourth model of capitalism can be found within the "order states". This category applies to several transition countries that are CIS members experiencing limited progress in political, and economic reforms (e.g. Belarus, Uzbekistan). These nations have undergone systemic transformation since 1990 with regard to integration with the world economy; that is, utilization of price mechanisms, domestic price levels close to the world level, and the development of private undertakings. However, substantial state ownership and the ubiquitous involvement of the government in the economy still remains [Drahokoupil, Myant, 2015, pp. 155-171]. The prominent institutional features of the "order states" are: "authoritarian political systems"; " [a] dominant role of the state in [the] economic decision-making [processes]"; " [government] support for commodity, or manufactured exports as a [form of] international integration [inherited from the past]"; " [a] poor environment for private business [development]"; and " [a] high level of welfare provision [that reflects the continuity of the socialist system legacy]" [Maszczyk, Rapacki, 2012, p. 143]. 
High levels of public spending within these countries ensure the popular support required to prolong the political survival of authoritarian regimes. This peculiar feature distinguishes the "order states" from many other CIS economies, in which welfare payments were significantly reduced during the systemic transformation in the early $1990 \mathrm{~s}$. For example, Belarus significantly benefits from its close relationship with Russia, exporting processed petrochemical products to that market and exporting vehicles, produced by the local enterprises which were established, under the former central planning system of the Soviet Union. In Belarus, the government owns the strategic enterprises and directs the lending policies of the state-owned banking system. Thus, strategic firms in this country have the required funding and managerial stability that is often lacking in the privatized companies of the Baltic States. However, the Belorussian enterprises are able to compete internationally only in undemanding markets not dominated by well-established multinational corporations (MNCs). The progress of "order states" relative to other "varieties of capitalism" largely depends on the scope of radical reform undertaken by these countries. Moreover, this model may turn out to be transient in nature for the representative post-socialist economies [Drahokoupil, Myant, 2015, pp. 155-171].

Finally, the fifth category of a capitalist system is present in the "remittance and aidbased economies". This applies to low-income peripheral SECC countries (e.g. Albania, Bosnia-Herzegovina) and many low-income CIS nations (e.g. Armenia, Kyrgyzstan, Moldova, Tajikistan, and Uzbekistan) [Drahokoupil, Myant, 2015, pp. 155-171]. The "remittance and aid-based economies" model is compatible with a very low-level of economic and political development of formal institutions. These nations are highly dependent on favorable labor market conditions in other countries (e.g. developed European Union nations or Russia) for the supply of foreign currency. Moreover, "remittance and aidbased economies" do not have the internal institutional preconditions (e.g. state capacity, structure of business, etc.) to ensure the presence of advanced forms of integration with the world economy [Maszczyk, Rapacki, 2012, p. 143]. The continual migration of many qualified workers in search for jobs to developed capitalist countries further limits the internal progress. The domestic business of these countries is restricted to small-scale trading because they lack a supportive economic and political environment and often face an unfavorable geographical location. Moreover, in many Central Asian nations (i.e. current CIS members), foreign currency remittances are spent on consumption and imports, and not on investment, which would bring more positive economic impact. The most likely medium-term future for these countries is as "peripheral market economies". This model depends on developing institutional environment for business and infrastructure that attracts multinational corporations (MNCs) for subcontracting. The remote geographical location of many of these countries may further hinder their transition to other "varieties of capitalism" [Drahokoupil, Myant, 2015, pp. 155-171].

Table 2. provides a summary of the main features of the classification proposed by Myant, Drahokoupil [2011, 2015]. Specifically, it presents the characteristics of the five 
identified models that emerged within the CEECs, SEECs and CIS's. It also predicts future progress from one model to another (classified within each "ideal type"). The different capitalist models shown in Table 2. are arranged from the most (i.e. "FDI based-second rank-market economies") to the least advanced (i.e. "Remittance and aid-based economies").

\section{TABLE 2. Summary of the main features of the "varieties of capitalisms" classification proposed by Myant and Drahokoupil [2011, 2015]}

\begin{tabular}{|c|c|c|c|c|c|}
\hline \multirow[b]{2}{*}{$\begin{array}{c}\text { Main features } \\
\text { of capitalist } \\
\text { systems }\end{array}$} & \multicolumn{5}{|c|}{ Ideal models (varieties) of the capitalist system distinguished within transition countries } \\
\hline & $\begin{array}{l}\text { FDI based } \\
\text { (second } \\
\text { rank) market } \\
\text { economies }\end{array}$ & $\begin{array}{l}\text { Peripheral } \\
\text { market } \\
\text { economies }\end{array}$ & $\begin{array}{l}\text { Oligarchic } \\
\text { (clientelistic) } \\
\text { capitalism }\end{array}$ & Order states & $\begin{array}{l}\text { Remittance } \\
\text { and aid-based } \\
\text { economies }\end{array}$ \\
\hline $\begin{array}{l}\text { Representative } \\
\text { countries }\end{array}$ & $\begin{array}{l}\text { Czech Republic, } \\
\text { Poland }\end{array}$ & Bulgaria, Latvia & Russia, Ukraine & $\begin{array}{l}\text { Belarus, } \\
\text { Uzbekistan }\end{array}$ & $\begin{array}{l}\text { Armenia, } \\
\text { Tajikistan }\end{array}$ \\
\hline $\begin{array}{l}\text { Main channel } \\
\text { of integration } \\
\text { with the world } \\
\text { economy }\end{array}$ & $\begin{array}{l}\text { Export-oriented } \\
\text { FDI in complex } \\
\text { sectors }\end{array}$ & $\begin{array}{l}\text { Simple } \\
\text { manufacturing } \\
\text { subcontracting } \\
\text { to MNCs }\end{array}$ & $\begin{array}{l}\text { Commodity } \\
\text { exports } \\
\text { and semi- } \\
\text { manufacturing }\end{array}$ & $\begin{array}{l}\text { Export-oriented } \\
\text { complex sectors } \\
\text { without FDI }\end{array}$ & $\begin{array}{l}\text { Dependence on } \\
\text { remittances and } \\
\text { financial aid }\end{array}$ \\
\hline State capacity & $\begin{array}{l}\text { Stable business } \\
\text { environment } \\
\text { requirement. } \\
\text { Separation of } \\
\text { enterprises } \\
\text { from direct } \\
\text { political } \\
\text { influence } \\
\text { by state } \\
\text { authorities. }\end{array}$ & $\begin{array}{l}\text { Stable business } \\
\text { environment } \\
\text { requirement. } \\
\text { Independence } \\
\text { of business } \\
\text { from the } \\
\text { influence of } \\
\text { political power. }\end{array}$ & $\begin{array}{l}\text { Special } \\
\text { protection } \\
\text { required } \\
\text { only for key } \\
\text { enterprises } \\
\text { in the country. } \\
\text { Independence } \\
\text { of business } \\
\text { from political } \\
\text { power } \\
\text { not specifically } \\
\text { needed. }\end{array}$ & $\begin{array}{l}\text { Special } \\
\text { protection } \\
\text { needed only } \\
\text { for strategic } \\
\text { companies } \\
\text { in the export- } \\
\text { oriented } \\
\text { industries. } \\
\text { Close } \\
\text { relationship } \\
\text { present between } \\
\text { political power } \\
\text { and strategic } \\
\text { companies. }\end{array}$ & $\begin{array}{l}\text { No specific } \\
\text { requirements } \\
\text { needed. }\end{array}$ \\
\hline $\begin{array}{l}\text { State } \\
\text { involvement } \\
\text { in the } \\
\text { economy }\end{array}$ & $\begin{array}{l}\text { Develops } \\
\text { substantial } \\
\text { infrastructure } \\
\text { for local } \\
\text { economy and } \\
\text { favorable } \\
\text { conditions for } \\
\text { FDI by MNCs. }\end{array}$ & $\begin{array}{l}\text { Provision } \\
\text { of basic } \\
\text { infrastructure } \\
\text { for the local } \\
\text { economy. }\end{array}$ & $\begin{array}{l}\text { Provision } \\
\text { of basic } \\
\text { infrastructure } \\
\text { for the local } \\
\text { economy. } \\
\text { The state may } \\
\text { offer special } \\
\text { support for key } \\
\text { enterprises. }\end{array}$ & $\begin{array}{l}\text { State protection } \\
\text { and support } \\
\text { may be } \\
\text { restricted } \\
\text { to specific areas } \\
\text { of the economy } \\
\text { and strategic } \\
\text { industries. }\end{array}$ & $\begin{array}{l}\text { State } \\
\text { engagement } \\
\text { in the local } \\
\text { economy not } \\
\text { required. }\end{array}$ \\
\hline
\end{tabular}




\begin{tabular}{|c|c|c|c|c|c|}
\hline \multirow[b]{2}{*}{$\begin{array}{c}\text { Main features } \\
\text { of capitalist } \\
\text { systems }\end{array}$} & \multicolumn{5}{|c|}{ Ideal models (varieties) of the capitalist system distinguished within transition countries } \\
\hline & $\begin{array}{l}\text { FDI based } \\
\text { (second } \\
\text { rank) market } \\
\text { economies }\end{array}$ & $\begin{array}{l}\text { Peripheral } \\
\text { market } \\
\text { economies }\end{array}$ & $\begin{array}{c}\text { Oligarchic } \\
\text { (clientelistic) } \\
\text { capitalism }\end{array}$ & Order states & $\begin{array}{l}\text { Remittance } \\
\text { and aid-based } \\
\text { economies }\end{array}$ \\
\hline $\begin{array}{l}\text { Financial } \\
\text { system } \\
\text { requirements }\end{array}$ & $\begin{array}{l}\text { Complex } \\
\text { financial system } \\
\text { and developed } \\
\text { capital markets } \\
\text { are not critical } \\
\text { preconditions } \\
\text { for FDI by } \\
\text { MNCs. }\end{array}$ & $\begin{array}{l}\text { Independent } \\
\text { sources of } \\
\text { finance may be } \\
\text { needed for local } \\
\text { enterprises. }\end{array}$ & $\begin{array}{l}\text { Large } \\
\text { enterprises } \\
\text { in strategic } \\
\text { sectors of } \\
\text { the economy } \\
\text { may require } \\
\text { financial } \\
\text { assistance from } \\
\text { the state or } \\
\text { seek external } \\
\text { funding (e.g. } \\
\text { banking system } \\
\text { and/or capital } \\
\text { markets). }\end{array}$ & $\begin{array}{l}\text { State can } \\
\text { direct funding } \\
\text { for strategic } \\
\text { export-oriented } \\
\text { enterprises } \\
\text { through } \\
\text { influence over } \\
\text { the domestic } \\
\text { banking system. }\end{array}$ & $\begin{array}{l}\text { No specific } \\
\text { financial system } \\
\text { requirements } \\
\text { needed. }\end{array}$ \\
\hline $\begin{array}{l}\text { Possible } \\
\text { prospective } \\
\text { direction for } \\
\text { change }\end{array}$ & $\begin{array}{l}\text { Some countries } \\
\text { may advance } \\
\text { to mature and } \\
\text { stable market } \\
\text { economies } \\
\text { subject } \\
\text { to substantial } \\
\text { development } \\
\text { of independent } \\
\text { innovation } \\
\text { capacity. }\end{array}$ & $\begin{array}{l}\text { Prospects of } \\
\text { advancement } \\
\text { to FDI based } \\
\text { (second } \\
\text { rank) market } \\
\text { economies if } \\
\text { export-oriented } \\
\text { manufacturing } \\
\text { capacity } \\
\text { in complex } \\
\text { sectors of the } \\
\text { economy is } \\
\text { developed. }\end{array}$ & $\begin{array}{l}\text { Progress } \\
\text { to more } \\
\text { developed } \\
\text { capitalist } \\
\text { models } \\
\text { requires radical } \\
\text { political and } \\
\text { social system } \\
\text { changes. Strong } \\
\text { relationships } \\
\text { between } \\
\text { business and } \\
\text { politics hamper } \\
\text { the scope for } \\
\text { new business } \\
\text { development. }\end{array}$ & $\begin{array}{l}\text { Transition } \\
\text { to advanced } \\
\text { varieties of } \\
\text { capitalism } \\
\text { depend on } \\
\text { the extent of } \\
\text { radical political } \\
\text { and economic } \\
\text { reforms } \\
\text { undertaken } \\
\text { with very } \\
\text { uncertain } \\
\text { consequences. }\end{array}$ & $\begin{array}{l}\text { Possibility of } \\
\text { development } \\
\text { to a peripheral } \\
\text { market } \\
\text { economy } \\
\text { subject } \\
\text { to improvements } \\
\text { in institutional } \\
\text { conditions. } \\
\text { Likely } \\
\text { progress may } \\
\text { be hindered } \\
\text { by remote } \\
\text { geographical } \\
\text { location. }\end{array}$ \\
\hline
\end{tabular}

Note: The acronym FDI refers to "Foreign Direct Investment," while the acronym MNCs means "Multinational corporations". S o u r c e s : own elaboration based on Myantand, Drahokoupil [2010, pp. 7-31]; Myantand, Drahokoupil [2011, pp. 299-312]; Maszczyk, Rapacki [2012, pp. 133-144]; Drahokoupil, Myant [2015, pp. 155-171].

\section{Conclusion and Recommendations}

This paper described and evaluated three popular approaches to the "varieties of capitalism". stream of research. We argued that existing classifications are not suitable 
to economic and political changes that have occurred within transition countries since 1990 as these frameworks focus on analyzing mature and stable capitalist economies. In turn, Drahokoupil and Myant [2011, 2015], adopting the "spirit" of the "comparative capitalisms" paradigm, proposed a comprehensive classification that combines six channels of international integration with five key institutions, which best describe the unique features of the post-socialist economies. These five ideal types of "varieties of capitalism" have emerged through transition from the CEECs, SEECs and CIS groups. Such typology provides more insights, and a broader understanding of the divergent levels of progress these countries have accomplished since 1990.

However, the classification advanced by Drahokoupil and Myant [2011,2015] also suffers from several limitations. The first drawback is associated with the limited evaluation of the progress made by transition countries, which underwent systemic transformation from central planning to market-based economies. In addition, the current literature fails to address a more comprehensive typology that would include the diversity of capitalist systems in different geographical regions. However, this classification can serve as a useful starting point for future research to include other emerging, but not yet developed economies (e.g. China, India, Brazil, South Africa, Mexico, Indonesia, Turkey, etc.). For instance, including China with its unique institutional structure of the business environment, specific economy characteristics, non-formal institutions (e.g. "guanxi" personal, business or government networks) ${ }^{2}$, as well as its prevailing channel of international integration, could further expand our understanding of the diversity of today capitalist systems.

The second limitation of this framework stems from the authors' failure to consider some emerging forms of international integration, such as foreign direct investments (FDI) from transition countries, especially after the global 2007-2008 financial crisis. The importance of this additional channel of integration with the world economy is steadily increasing for some transition countries like Russia (e.g. FDI of Lukoil Overseas Oil Company in Kazakhstan, Saudi Arabia, and Uzbekistan), as well as Poland (e.g. FDI of KGHM International Ltd. in Canada, Chile, and the USA) ${ }^{3}$. Therefore, further research on the impact of this development on transition economies in the context of the "comparative capitalisms" theoretical frameworks is needed.

Finally, the third drawback of literature classification stems from its failure to consider additional factors, beyond formal and informal institutions, as well as different forms of international integration that best describe the diversity of capitalist systems emerging in the post-socialist countries since 1990. For instance, in some countries factors such as national culture (e.g. Russia); religion (e.g. Turkmenistan, Uzbekistan); geographical location (e.g. Armenia, Moldova); social capital (e.g. Russia); education and skills formation (e.g. Czech Republic, Poland); and the use of information and telecommunication (ICT) technology (e.g. Poland, Russia), could also be important in developing "varieties of capitalism" classifications. 
Therefore future research in this area should expand the range of variables to better capture the complex and unprecedented nature of systemic transformations being undertaken by transition economies. Prospective studies could also take into account the impact of supra-national organizations (e.g. the European Commission; the World Trade Organization, etc.) on the behavior of the economic agents in transition countries, and the influence these institutions may have on the development of classifications of post-socialist economies.

In conclusion, the classification proposed by Drahokoupil and Myant [2011, 2015] of five "ideal models" of the capitalist system, prevalent within the transition countries, should not be viewed as "final". Instead, dynamic models that capture economies in which established institutions and channels of international integration are evolving should be considered. These changes may lead to the emergence of new institutional patterns within transition economies. As a result, future transition countries may move from one variety of capitalism to another type, which may require a modification of the classification of market-based systems existing in post-socialist nations. For instance, some "ideal models" could disappear altogether from this typology, while other categories may emerge within the "comparative capitalisms". Furthermore, other comprehensive classifications may be developed that include a broader range of variables and countries.

Finally, this paper has focused on the "varieties of capitalism" literature concentrating on analyzing the differences between economies and their development by using either one country or country groups as a unit of analysis. In future research it may also be worthwhile to examine the diversity of capitalist systems, which may be potentially distinguished within different geographical, or even administrative regions of a particular country (e.g. Russia, China, Brazil, etc.). Such research findings can then be used for comparative purposes to provide new insights regarding evolving capitalism.

\section{Notes}

1 Author’s e-mail address: dariusz.leszczynski@gmail.com

2 "Quanxi" relationships (i.e. networks) are a form of social capital that is widely present within the Chinese society. It is culturally determined, non-formal and intangible in nature. These types of relationships are used predominantly by men in their personal, business or government-related connections, as well as networks. They may be used to overcome many business barriers such as the access to external financing [Scott et al., 2010, pp. 52-56].

3 The information on FDI of the Lukoil Overseas Oil Company was obtained from the firm's official website at: http://lukoil-overseas.com/projects/, (accessed: November 27, 2015). In turn, the information 
on FDI of KGHM International Ltd. was taken from the company's official website at: http://kghm. com/pl/o-nas/kghm-na-swiecie, (accessed: November 27, 2015).

\section{References}

Amable, B. (2003), The Diversity of Modern Capitalism, First ed. Oxford: Oxford University Press.

Bohle, D., Radice, H., Shields, S. (2007), Introduction. Competition and Change, 11(2), pp. 81-87.

Coates, D. (2000), Models of Capitalism. Growth and Stagnation in the Modern Era, First ed., Cambridge: Polity Press.

Coates, D. (2006), Models of Capitalism. Growth and Stagnation in the Modern Era, Third ed. Cambridge: Polity Press.

Drahokoupil, J., Myant, M. (2015), Putting Comparative Capitalisms Research in Its Place: Varieties of Capitalism in Transition Economies, in: M. Ebenau, I. Bruff, C. May (eds.), New Directions in Critical Comparative Capitalisms Research: Critical and Global Perspectives, First ed., New York, NY, Palgrave Macmillan, pp. 155-171.

Ebenau, M., Bruff, I., May, C. (2015), Introduction: Comparative Capitalisms Research and the Emergence of Critical, Glabal Perspectives, in: M. Ebenau, I. Bruff, C. May (eds.), New Directions in Comparative Capitalisms Research: Critical and Global Perspectives, First ed., New York, NY: Palgrave Macmillan, pp. 1-8.

Hall, P.A., Soskice, D. (2001), An Introduction to Varieties of Capitalism, in: P.A. Hall, D. Soskice (eds.), Varieties of Capitalism: The Institutional Foundations of Comparative Advantage, Oxford, Oxford University Press.

Hardy, J. (2014), Transformation and crisis in Central and Eastern Europe: A combined and uneven development perspective, Capital \& Class, 38(1), pp. 143-155.

Heiduk, G.S., Rapacki, R. (2009), The Road from Plan to Market: Comparing Poland and China, in: R. Frank and S. Burghart (eds.), North Korea, East Asia, and the Transformation of Socialist Systems: Institutional Frameworks and the European Experience, Vienna: Praesens Verlag, pp. 187-221.

KGHM Polska Miedź (2015), KGHM na świecie, [online], available at: http://kghm.com/pl/o-nas/kghm-naswiecie, (accessed: November 27, 2015).

Kornai, J. (2000), What the Change of System from Socialism to Capitalism Does and Does Not Mean, Journal of Economic Perspectives, 14(1), pp. 27-42.

Lane, D. (2005), Emerging Varieties of Capitalism in Former State Socialist Societies, Competition and Change, 9(3), pp. 227-247.

Lane, D. (2007), Post-State Socialism: A Diversity of Capitalisms?, in: D. Lane, M. Myant (eds.), Varieties of Capitalism in Post-Communist Countries, New York, NY, Palgrave Macmillan, pp. 13-39.

Lukoil Oil Company (2015), Lukoil Overseas: Where we operate [online], available at: http://lukoil-overseas. com/projects/, (accessed: November 27, 2015).

Maszczyk, P., Rapacki, R. (2012), Varieties of Capitalism in Transition Countries, First ed., Warsaw, Collegium of World Economy at the Warsaw School of Economics (SGH).

Myant, M., Drahokoupil, J. (2010), Varieties of Capitalism in Transition Economies, Working paper [online], available at: http://ssrn.com/abstract=1561944, (accessed: May 27, 2012).

Myant, M., Drahokoupil, J. (2011), Transition Economies: Political Economy in Russia, Eastern Europe and Central Asia, First ed., Hoboken, NJ, John Wiley \& Sons Inc.

Polanyi, K. (2001), The Great Transformation: The Political and Economic Origins of our Time, Second ed., Boston, MA, Beacon Press. 
Scott, J.M., Hussain, J., Harrison, R.T., Millman, C. (2010), China, in: S.L. Fielden, M.J. Davidson (eds.), International Research Handbook on Successful Women Entrepreneurs, Cheltenham, Edward Elgar Publishing Ltd., pp. 49-59. Streeck, W. (2010), E Pluribus Unum? Varieties and Commonalities of Capitalism, Discussion Paper 10/12, Cologne, Max Planck Institute for the Study of Societies. 